DOI: $10.1515 / \mathrm{rrlm}-2017-0001$

\title{
Microbial biofilm in human health - an updated theoretical and practical insight
}

\section{Biofilmul microbian în medicină - o perspectivă teoretică și practică}

\author{
Monica Licker ${ }^{1,2}$, Roxana Moldovan ${ }^{1}$, Elena Hogea ${ }^{1,3}$, Delia Muntean ${ }^{4, *}$, \\ Florin Horhat $^{1,2}$, Luminița Baditoiu ${ }^{1,5}$, Alexandru Florin Rogobete ${ }^{1}$, \\ Emil Tîrziu ${ }^{6}$, Csilla Zambori ${ }^{1}$
}

', Victor Babeș” University of Medicine and Pharmacy Timişoara, Romania 2,,Pius Branzeu”

Emergency, Clinical, County Hospital Timișoara, Romania, ${ }^{3}$, Victor Babeș" Clinical Infectious Diseases Hospital Timișoara, Romania, ${ }^{4}$ Department of Microbiology, , Victor Babeș” University of Medicine and Pharmacy Timișoara, Romania, ${ }^{5}$ Regional Centre of Public Health Timișoara, Romania,

${ }^{6}$ Banat's University of Agricultural Sciences and Veterinary Medicine, King Michael I of Romania,

Timişoara, Romania

\begin{abstract}
The term biofilm designates an aggregate of microorganisms belonging to one or more species which adhere to various surfaces but also to each another. These microbial communities are included and interconnected within an organic structure known as slime, composed of protein substances, polysaccharides, and DNA.

The Center for Disease prevention and control considers infections with bacteria in biofilms among the 7 most important challenges which must be overcome in order to improve the safety of health services. The risk of microbial biofilm development exists for a long list of medical devices and equipment, as well as in certain diseases such as cystic fibrosis. An aggravating aspect is represented by the almost 1,000 times higher antimicrobial resistance of bacteria growing and multiplying within biofilms. Thus, in case of biofilm-infected medical devices, the resistance to antimicrobial treatments requires the removal of the device which essentially means the failure of the exploratory or therapeutic intervention in question.

The role of microbial biofilms in medical pathology is a subject that raises interest for both researchers and clinicians in order to establish new methods for prevention and treatment of biofilms. This paper is intended as an overview in the management of microbial biofilms, presenting future insights, with technological progress in microscopy, molecular genetics, and genome analysis. Therefore the present paper will focus on describing the mechanisms involved in biofilm development, biofilm related infections, methods of detection and quantification of microbial communities and therapeutical approaches.
\end{abstract}

Keywords: biofilm; medical devices; microscopy.

* Corresponding author: Delia Muntean, Department of Microbiology, „Victor Babeș” University of Medicine and Pharmacy, Str. E. Murgu Nr. 2, Timișoara, Romania, e-mail: deliacristimuntean@yahoo.com 


\section{Rezumat}

Termenul de biofilm desemnează agregate de una sau mai multe specii microbiene aderente la diferite suprafețe, în care celulele sunt, de asemenea, unite și între ele. Aceste comunități microbiene sunt incluse și solidarizate într-o structură organică desemnată drept ,slime” în a cărei componență intră substanțe proteice, polizaharide, ADN. Centrul pentru Controlul și Prevenția Bolilor consideră că infecțiile cu bacterii din biofilme se situează printre cele mai importante 7 provocări ce trebuie depășite, pentru creșterea siguranței serviciilor de sănătate.

Riscul dezvoltării de biofilme bacteriene există pentru o lungă listă de dispozitive și echipamente medicale, precum și afecțiuni, cum ar fi fibroza chistică. Un aspect agravant îl reprezintă rezistența la antibiotice, care este de până la de 1000 de ori mai mare în cazul bacteriilor înglobate în biofilme. Astfel, în cazul dispozitivelor medicale infectate, rezistența la tratamentul antibacterian duce la necesitatea îndepărtării acestora, ceea ce reprezintă de fapt eșecul respectivei intervenții medicale exploratorii sau terapeutice.

Rolul biofilmelor microbiene în patologia medicală reprezintă un subiect care polarizează în egală măsură interesul clinicienilor și al cercetătorilor, în vederea identificării de noi metode de prevenție și tratament al acestora. Acest articol dorește să facă un rezumat al managementului biofilmelor microbiene, cu prezentarea perspectivelor, a progreselor înregistrate în microscopie, genetica moleculară și analiza genomică. Prin urmare, lucrarea de față se va concentra pe descrierea mecanismelor implicate în formarea biofilmului, infecțiilor produse de biofilme, metodelor de detectare și cuantificare a comunităților microbiene și a noilor abordări terapeutice.

Cuvinte cheie: biofilm; dispozitive medicale; microscopie.

Received: $8^{\text {th }}$ August 2016; Accepted: 12 th December 2016; Published: $31^{\text {th }}$ December 2016.

\section{Introduction}

Van Leeuwenhoek was the first to discover minute living creatures, using lenses made by himself after he examined saliva, leaves of plants, faeces, soil samples, etc. He also collected portions of his dental plaque and used the above-mentioned lenses to examine the material in which he observed minute organisms which he called "animalcules" (1).

Much later, in 1976, Marshall detected "very fine extracellular polymer fibrils" which he identified as means of bacterial adherence to various surfaces. In 1978, the term 'biofilm' was formally introduced by Costerton (2), who observed that communities of bacteria found in aquatic systems were enclosed in a "glycocalyx" matrix, which was shown to mediate adhesion.

In the last few years, there has been an increased focus on the biofilm generating potential of a group of clinically relevant bacteria, causing high mortality, abbreviated with the acronym ESKAPE which stands for Enterococcus faecalis, Staphylococcus aureus, Klebsiella pneumoniae,
Acinetobacter baumannii, Pseudomonas aeruginosa and Enterobacter spp. Additionally, biofilm formation apparently plays a role in dental caries, with the proven involvement of bacteria such as Streptococcus sobrinus and Streptococcus mutans. Another interesting area requiring further research is represented by the mechanisms of biofilm development in cases of implant contamination by microorganisms such as Proteus mirabilis (3).

The Center for Diseases prevention and control (CDC) listed biofilm-related pathology among the most important safety challenges confronting health care systems and consequently, research work focusing on understanding the intimate mechanisms of biofilm formation and functioning. According to CDC experts, such research involving innovative techniques in microscopy and molecular biology helped the scientific community to better understand the structure and functioning of biofilms, with important advances in the management of infections caused by biofilms. The percentage of biofilm-related health care-associated infections has been estimated at over $65 \%$ (4). 
According to the European Society of Clinical Microbiology and Infectious Diseases Biofilms study group (ESGB), new methods are necessary for studying biofilm-associated infections in humans. Such methods are only used in specialized research laboratories. The ultimate goal of ESGB is to improve the results of prophylaxis and therapy of biofilm-associated infections in humans. In order to obtain these goals, ESGB realizes that a multidisciplinary approach is necessary, including scientists from basic and environmental microbiology, as well as molecular microbiology $(5,6)$.

\section{Biofilm definition}

The present definition of a biofilm could be formulated as an aggregate of one or more microbial species which adhere to various surfaces but also to one another. These microbial communities are included and interconnected within an organic structure designated with the term of extracellular polymeric substance (EPS), also known as "slime", composed of proteic substances, polysaccharides, and DNA $(1,2,3)$.

There are several common characteristics of biofilms developing on diverse solid areas e.g. heterogeneous structure, multiple interrelations between the components, diverse genetic features, strong, irreversible attachment to living or inanimate surfaces (1). The rising occurrence of biofilm-related pathology is explainable by the increasing frequency of exploratory and/or therapeutic procedures involving the use of implanted medical devices.

\section{Mechanisms of Biofilm generation and development}

The first stage of biofilm generation requires microorganisms to adhere to a surface. The adhesion is initially weak, as it is achieved through van der Waals forces; an important aspect is the reversible character of biofilm generation at this initial stage. In other words, should any factors act to detach the microbes from the respective surface during this early stage, biofilm formation would be prevented. Whenever there is no external early action taken against microbial attachment to that surface, the adherence will increase and tend to become permanent due to the involvement of cell adhesion structures e.g. pili $(1,2,3,7)$.

Thus, in the case of an implanted medical device or equipment which has been contaminated by microorganisms, the chance of further biofilm development with consecutive infection depends on a number of variables. As stated above, the presence of microorganisms on the device must last long enough in order for the initial stage of weak, reversible attachment to be transformed into the quasi-permanent adherence. The number and types of cells in the exposure environment of the implanted device, the liquid flow rate (in the case of lumen devices), and the physico-chemical structure of the implanted material may be listed among the most important variables involved. To sum up, the main stages of biofilm initiation and development may be defined as follows: microbial adherence, colony formation, biofilm maturation and final dispersion (Figure 1). During each of these stages, microorganisms may benefit from internal or external supportive structures (pili, DNA or exopolysaccharides) $(1,2,3,7,8)$.

\section{Bacterial growth and multiplication sup- ported by biofilm}

Biofilm formation is a naturally occurring phenomenon encountered in the external environment and impacting various aspects of human life, such as contamination of foods, corrosion and/or obstruction of pipes, etc. Similarly, such phenomena also occur within the human body resulting, for instance, in dental plaque formation, mastitis, otitis, pneumonia, urinary tract in- 


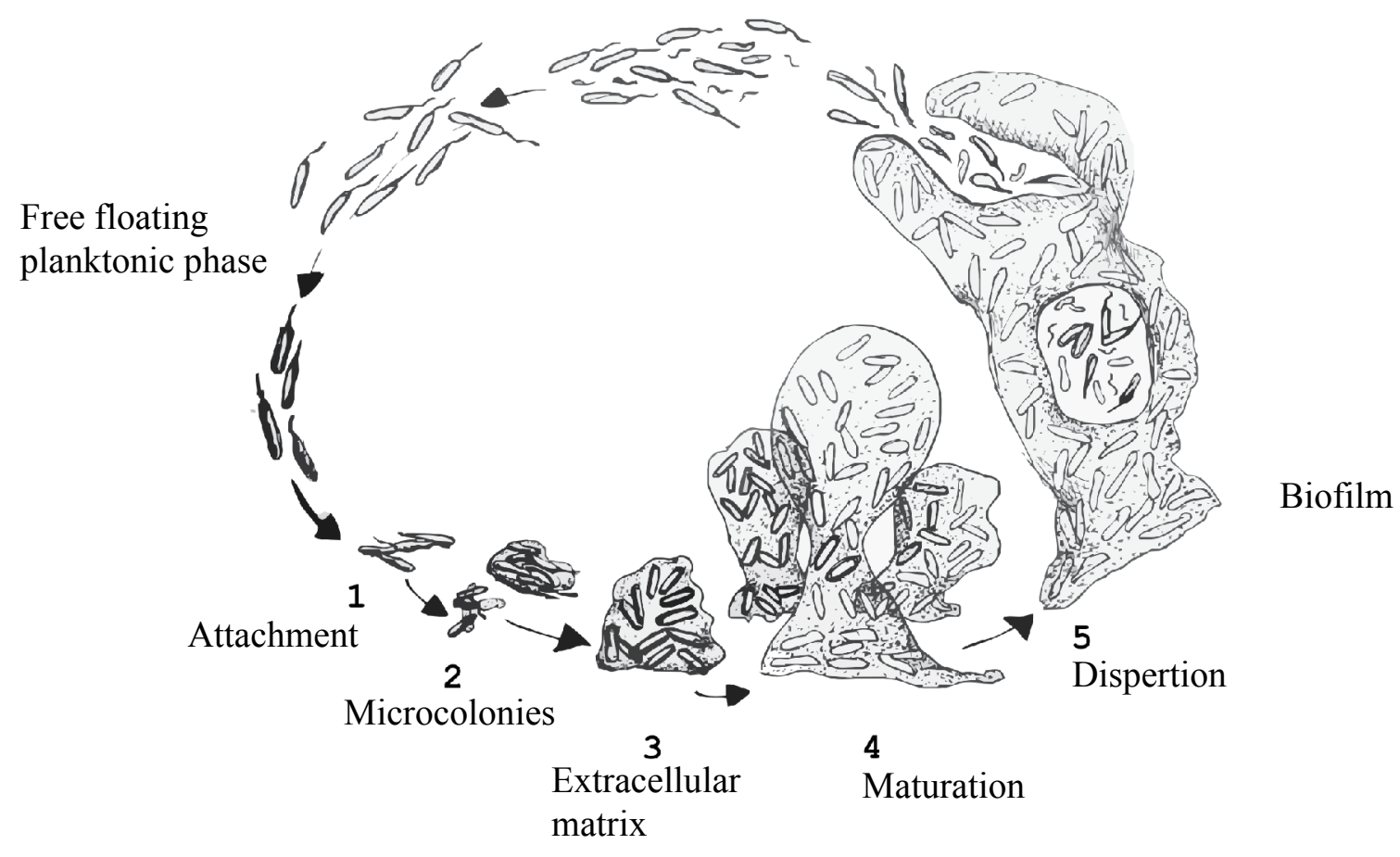

Figure 1. Stages in biopfilm development

fections (UTI), osteomyelitis, as well as biofilm contamination of implanted medical devices and equipments. The most frequently involved microorganisms responsible for biofilm formation on implanted devices include Gram-positive bacteria (GPB), Gram-negative bacteria (GNB) and fungi (Table 1). Whenever such microorganisms grow and multiply within biofilms, several characters might differ as compared to their counterparts not being hosted by biofilms. This is mainly due to the protection provided by biofilm components which allow bacteria to interact with mutual advantages e.g. higher resistance to detergents and antimicrobials granted by the extracellular matrix acting as a protecting shield (1, $2,3,7,5,9,10)$.

Therefore, biofilms are found to be involved in a wide variety of microbial infections which can be classified into three main categories: biofilm organ-related infections, biofilm implant-related infections and biofilm related waterborne diseases.

In cystic fibrosis patients the airways are filled with an adherent and consistent mucus favored by biofilms, resulting in severe breathing problems. Pseudomonas infections often result in antibiotic-resistant biofilms. Moreover, in such cases biofilms might contain virulence factors, such as the major polysaccharide of P.aeruginosa matrix (alginate), with consecutive pulmonary lesions $(3,9)$.

\section{Wounds}

Biofilms are commonly found in chronic wounds, being present either at the surface or within the profound layers (as is the case of P.aeruginosa biofilms) and contributing to delayed wound healing. The microbiological diagnosis of these infections is usually difficult to achieve by simply swabbing the wound and culturing the sample $(10,11)$. 
Table 1. Predominant microorganisms responsible for biofilm formation $(1-10,23,26,48)$

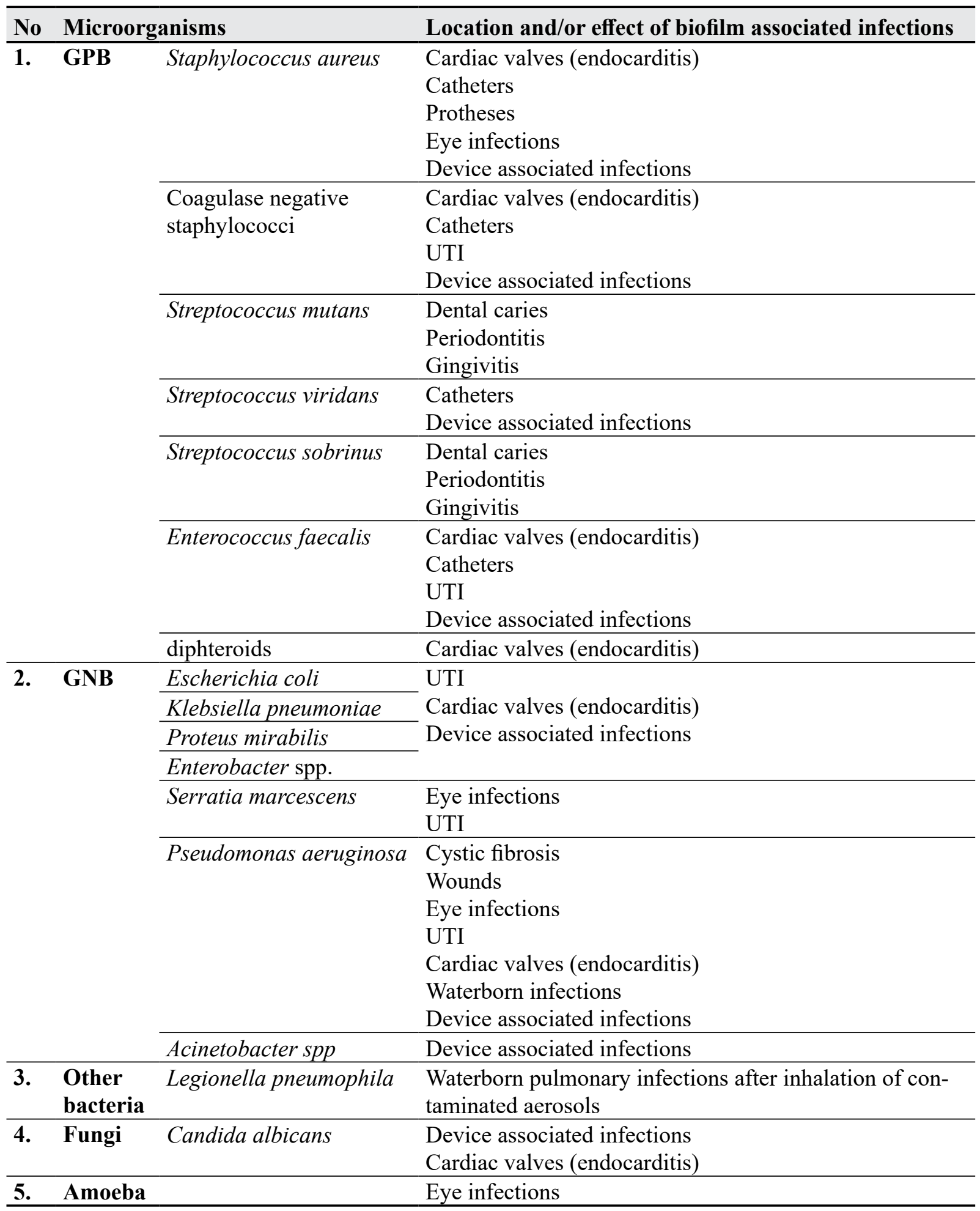


There is a global increase of chronic wounds especialy in obesity and diabetes patients. These patients are particularly prone to be colonized by a high number of bacterial species (12).

Dower et al. described biofilms already present on wound drains removed even after only 2 hours after placement and they observed that even when increased attention to sterility was involved upon placement of wound drains, the amount of biofilm was not significantly lower. Their conclusion was that within 2 hours after drain placement on closed suction wounds, biofilms will develop (13).

\section{Dental plaque}

Biofilms play an important role in dentistry with more than 700 bacterial species in the dental plaque where mixed biofilms are present. The unique conditions in the oral cavity including moisture, thermic variations, presence of hard tissues, as well as the presence of carbon and nitrogen, make this a suitable environment for many microbial species. The bacterial componence of biofilms is dependent on factors within this complex and variable environment. For example, the combined action of intraoral acidity (e.g. acid foods on dental surfaces) and the dental adherence and growth of S.sobrinus and S.mutans, which are acid-tolerant bacteria, highly contribute to various oral diseases such as dental caries, periodontal disease, gingival inflammation, etc. Bacterial inter-communication is a paramount process supporting colonization and biofilm formation on the dental enamel. Once biofilm formation has been consolidated, the protective shield provided by non-bacterial biofilm components will further support information exchanges between biofilm bacteria, contributing to important aspects such as resistance to antiseptics and/or antibiotics $(3,14,15)$.

\section{Biofilms - a great threat to implants}

As previously stated, biofilm formation significantly influences the evolution of implanted medical devices: intravenous catheters, prosthetic joints, breast and other implants, contact lenses, artificial cardiac valves, or pacemakers. This also applies to dental implants which need to be protected as well as possible from contamination with the extremely rich oral bacterial flora, in order to avoid infection with consecutive implant failure. Once microbial colonization occurs on such medical devices, chronic, slowly evolving, persistent infections may develop. The incidence of such complications is expected to rise with the increased use of implanted medical devices and equipments $(3,10,16,17,18)$.

\section{Biofilm-related endocarditis}

In patients with artificial cardiac valves, microbial colonization of these prosthetic devices and of the surrounding tissues with further biofilm development results in prosthetic cardiac valve endocarditis, which is a severe complication.

These infectious conditions may originate from the bacterial flora on the patient's skin but also from other implanted devices e.g. central intravenous catheters (CVC) or dental implants contaminated with S.epidermidis, S.aureus, Streptococcus spp., enterococci, diphtheroids, GNB, Candida spp. etc. Moreover, biofilm bacteria may sometimes enter the bloodstream with consecutive dissemination into other organs and tissues $(1,3)$.

\section{Biofilm-related ocular infections}

A number of materials and devices used in ophthalmology have been reported to be exposed to biofilm development. Among the most frequently involved devices, materials used for the surgery of retinal detachment (scleral buckling) were cited together with contact and intraocular lenses, materials used for sutures, etc. The 
infecting moment most frequently identified, is during surgical procedures involving the above-mentioned devices and/or materials which can become contaminated and further infected with the development of biofilms (1, $10,19,20)$. Also, in the case of eye contact lenses, the moisture required for their storage may represent a risk factor for biofilm development with consecutive infections of the ocular cornea. Literature data show that between 20 and $80 \%$ of persons wearing contact lenses may acquire corneal infections with fungi, bacteria, amoebae, originating from biofilm contamination of these devices and the cases in which they are stored (1). In a research conducted by Szczotka-Flynn et al., lotrafilcon A silicone hydrogel contact lenses were found to be contaminated with both reference and clinical strains of Serratia marcescens, P.aeruginosa and S.aureus, developing within biofilms and which resisted to solutions of biguanide compounds, common care solutions for such devices (18).

\section{Biofilm contamination of urinary catheters}

The contamination of latex or silicone tubes used for urinary catheterization may occur during the insertion, with biofilm development both on the outer and internal surfaces of these devices. The list of microorganisms most frequently involved in biofilm development in the lumen or on the outer surfaces of urinary catheters includes germs originating from the skin (e.g. Staphylococcus epidermid$i s$ ) or from the mucous membranes of the urogenital area, as well as from the intestinal flora (E.faecalis, E.coli, P.mirabilis, P.aeruginosa, K.pneumoniae). A very important factor influencing biofilm formation is the duration of catheterization. A prolonged time of contact between the biofilm contaminated catheter will favor a biofilm-related UTI $(1,3,10,21$, 22).

\section{Biofilm contamination of indwelling medi- cal devices}

Bacteria commonly isolated from indwelling medical devices include: E.faecalis, S.aureus, S.epidermidis, Streptococcus viridians, E. coli, K.pneumoniae, P.mirabilis, and P.aeruginosa or yeasts $(1,10)$.

Biofilm quantification in the case of CVC is achieved by the so-called roll-plate method which involves the removal of the catheter tip which is then rolled onto the surface of a non-selective culture medium, which is thus inoculated with the microbial contaminants, if any. The number of colony forming units (CFU) on the culture medium will represent a quantification of the microbial load of the catheter tip, this being considered as a reference technique for this purpose. The downside of this method is that sampling is limited to the catheter tip and it does not include the internal surface of the CVC and thus, there is no information regarding the microbial contamination and/or biofilm formation within the catheter lumen. As a consequence, this method has low levels of sensitivity and predictive value for detecting bacteremia cases originating from biofilm contaminated CVCs. There is also a quantitative limitation of this technique as no more than 1,000 CFU/ tip can be detected. Alternatively, preliminary sample preparation by sonication and vortexing improved quantification and the positive predictive value threshold for septicemia originating from biofilm contaminated CVCs was set at $104 \mathrm{CFU} /$ catheter tip (2).

\section{Endotracheal tubes}

Pneumonia in the ventilated, critically ill patients remains a complex disease with multifactorial etiology. Biofilms form on endotracheal tubes (ETT) and can impact airway resistance. According to Wilson et al., the lifecycle of a biofilm has four stages. Authors concluded that 
advanced biofilms stage (stage IV) is associated with pneumonia in ventilated patients. The duration of intubation does not appear to be related to biofilm stage $(23,24)$.

\section{Prosthetic joint infection}

Usually, GPB, such as staphylococci, are more frequently involved. In cases of blood or lymph bacterial contamination after surgical interventions performed for placement of articular prostheses, microorganisms adhere to the surface of the implanted medical device in question and biofilm generation begins. Such infections often evolve atypically and may escape detection due to the lack of symptoms, e.g. absence of fever during the early stages and the diagnosis of biofilm-related prosthetic joint infection is delayed to later stages when local pain appears (10).

\section{Biofilms and waterborne infections}

Biofilm contamination of healthcare water systems is also possible and requires an active and continuous risk management. All healthcare facilities should have water safety plans as part of their infection control programme that define responsibilities, design and maintenance, monitoring and action plans. Biofilm formation and water contamination of the healthcare water systems should be controlled and prevented through some simple interventions (like the use of micro-filters, shorter flexible shower hoses, systematic walk-through of the water system, etc.) (25).

\section{Influence of biofilms on antimicrobial treatment}

The antimicrobial resistance of microorganisms living and multiplying within biofilms may be up to 1,000 times higher than in the absence of biofilms. For this reason, in cases of biofilm contaminated implanted devices the antibiotic treatment often fails to solve the infection and surgery for implant removal is required $(1,9,10,26)$.

In a study conducted on biofilm contaminated contact lenses, Brothers et al. found that the effectiveness of treatments was severely influenced due to impaired drug diffusion through bandage contact lenses (19).

In a rat model developed by Arad E. et al. for silicone breast implants contaminated with methicillin-resistant $S$. aureus (MRSA), biofilm infection proved to be persistent, asymptomatic and with high resistance to vancomycin (27).

In the case of patients with prosthetic cardiac valves, antibiotics are prescribed before any dentistry procedures to prevent blood stream diffusion of oral cavity bacteria and their further adherence to the surface of the cardiac valves. This antibiotic prophylaxis is extremely important as, once a biofilm contamination and infection has occurred, antimicrobial treatment might not suffice and surgery for valve removal is often required.

Microorganisms in biofilms are resistant to antimicrobial agents, but not in the classic sense (by $\beta$ lactamases production, modification of targets, or exclusion of the antibiotic to their targets). Antibiotic resistance of biofilms is based upon the capacity of microorganisms to rely on complement of genes, as a result of microbial growth and development within the complex biofilm environment with an additional contribution of antibiotic pressure. In other words, biofilm antibiotic resistance can be defined as resulting from a combination of genetic and induced factors.

The genetic mechanisms of this biofilm antibiotic resistance are classified into two general classes: innate resistance factors and induced resistance factors. The innate mechanisms are considered as activated mechanisms of the biofilm development. These factors are considered as integral parts of biofilm structure and physiology and include: decreased diffusion of antibiot- 
ics through the biofilm matrix, decreased oxygen and nutrient availability accompanied by altered metabolic activity.

Induced resistance factors include those resulting from induction by the antimicrobial agent itself. Biofilm antibiotic resistance is mostly manifested as a mixture of innate and induced mechanisms $(2,9,28)$.

One of the most interesting aspects concerning the special situation of microorganisms growing inside the complex and protective environment provided by biofilms is the so-called quorum sensing. This phenomenon is based upon the capacity of bacteria to communicate in order to quantitatively regulate the biofilm content. For this, whenever bacterial populations reach a critical threshold, low molecular weight molecules are released. This process is involved in expressing bacterial factors of virulence and it explains the changed and, sometimes, increased virulence of microorganisms growing inside biofilms (1). QS operates through a wide range of signals such as: Oligopeptides (5-10 amino acid cyclic thiolactone), $\mathrm{N}$-acyl homoserine lactones (AHLs), Furanosyl borate (Autinducer-2, AI-2), Hydroxyl-palmitic acid methylester, and Methyl dodecanoic acid. QS inhibition is referred to inhibiting signal synthesis or direct degradation of the signal, inhibition of binding of the signal molecule to the receptor and/or inhibition of the signal transduction cascade (29).

The reasons why these modified phenotypes have not been previously detected might be related to their growth within highly nutritional, planktonic environments.

\section{Influence of biofilms on the immune system}

Biofilms provide microorganisms with protection against human specific and nonspecific defence mechanisms. Also, bacteria contribute to the development and growth of their protective biofilm by secreting enzymes which catalyze the synthesis of polysaccharides which favor adhesion to solid surfaces as well as colonization. These enzyme secretion processes are in fact triggered by the very contact of bacteria with the solid surfaces of implanted devices.

The resulting polysaccharide matrix which adheres to the solid surface offers effective protection against phagocytosis. The phagocytes, while unable to act upon biofilm-protected bacteria will still release high levels of cytokines and pro-inflammation factors causing inflammation and other cytokine-related lesions in the adjacent tissues $(1,2)$.

\section{Practical approach for biofilm detection}

Standard microbiological sampling is insufficient for detecting bacterial biofilm (31). The traditional approach for biofilms detection involves the recovery of live bacteria within the biofilm, the detection of biofilm by in vitro or in vivo techniques and subsequent identification and imaging of microbial communities on analyzed surfaces (Table 2).

\section{In vitro techniques for biofilm detection}

Microtitre plate assays (MTP)

MTP-based assays are the cheapest methods for biofilm detection as they involve small amounts of reagents while offering the possibility to run a range of tests in parallel. For all these reasons, these tests are best suited for screening (32).

MTP-based model systems are important in screening the effectiveness of antimicrobials, as well as of disinfectant substances, both synthetic and natural (extracted from plants) against biofilms. Another application of this model would be to improve the composition of impregnation materials by adapting them to biofilm development by regulation of various parameters (moisture level, the temperature of incubation, composition of growth media, shear stress, the concentration of oxygen and carbon dioxide) (33). 
Table 2. Practical approach for biofilm detection $(2,8,11,15,16,19,25-47)$

\begin{tabular}{|c|c|c|}
\hline No & Technique & Methods \\
\hline \multirow[t]{4}{*}{1.} & \multirow{4}{*}{$\begin{array}{l}\text { Detection of biofilm } \\
\text { by in vitro techniques }\end{array}$} & Microtitre plate assays \\
\hline & & In vitro flow displacement biofilm model systems \\
\hline & & In vitro microfluidic devices \\
\hline & & In vitro tissue Culture Plate, Tube method, Congo Red Agar method \\
\hline \multirow[t]{4}{*}{2.} & \multirow{4}{*}{$\begin{array}{l}\text { Detection of biofilm } \\
\text { by in vivo techniques }\end{array}$} & Non - vertebrate animal models \\
\hline & & Vertebrate animal models \\
\hline & & In vivo tissue - biofilm models \\
\hline & & In vivo device related infections - biofilm models \\
\hline \multirow[t]{5}{*}{3.} & \multirow{5}{*}{$\begin{array}{l}\text { Quantification of } \\
\text { microbial biofilm }\end{array}$} & Microtiter plates \\
\hline & & Techniques to determine the total biofilm biomass \\
\hline & & The number of viable sessile cells only \\
\hline & & The amount of extracellular polymers in the biofilm matrix \\
\hline & & Roll-plate technique for central venous catheters \\
\hline \multirow[t]{3}{*}{4.} & \multirow{3}{*}{$\begin{array}{l}\text { Visualization of } \\
\text { microbial biofilm }\end{array}$} & Scanning electron microscopy \\
\hline & & Epifluorescence microscopy \\
\hline & & Confocal laser scanning microscopy \\
\hline \multirow[t]{5}{*}{5.} & \multirow[t]{5}{*}{ Bacterial recovery } & Sonication and isolation \\
\hline & & Polymerase chain reaction \\
\hline & & Fluorescent in situ hybridization \\
\hline & & Metabolomic profiling and genomic analysis \\
\hline & & Multiple diagnostic techniques \\
\hline
\end{tabular}

In a study conducted by Zambory et al. (34), the authors aimed to assess the in vitro capacity of planktonic bacterial strains possibly involved in zoonoses to form biofilms. For this, supragingival samples were collected from dogs with dental diseases. Microbiological tests isolated and identified 75 strains of Staphylococcus, Streptococcus, Neisseria and Pasteurella. MTP was further used to assess the capacity of these microbial strains to generate biofilms and all the tested strains tested positive for biofilm formation capacity, with inter- and intraspecific differences (34). In another study, conducted on adenoidectomised children, nasopharyngeal swabs, and adenoid core were collected and the iso- lated and identified Haemophilus strains were tested for biofilm-forming capacity (35).

In vitro flow displacement biofilm model systems Such systems involve an in-flow of nutritive substances with the parallel removal of waste. The flow displacement biofilm model systems can be subdivided into two groups: either following the "continuous flow stirred tank reactor" (CFSTR) approach or the "plug flow reactor" (PFR) approach. An example of flow displacement model often used to study the oral biofilms is the constant depth film fermenter (CDFF). This CDFF was used to highlight the effect of some antimicrobial agents and the influence of surface roughness on biofilm development $(36,37)$. 
In vitro microfluidic devices

Such equipments support biofilm formation under different physiological conditions such as physiological flow velocities and low fluid-tocell volume ratios. The small sized chambers of the fluidic devices allow the high-resolution microscopic biofilm analysis and also offer a high precision environmental control (33).

In vitro tissue Culture Plate (TCP), Tube method (TM), Congo Red Agar method (CRA)

Afreenish Hassan et al. (38) have studied three different methods (TCP, TM, CRA) to detect biofilm forming microorganisms isolated from clinical specimens and to compare these methods for biofilm detection. They observed that compared to TM and CRA methods, TCP method can be used as a general screening model to detect biofilm generating bacteria.

\section{In vivo techniques for biofilm detection}

Non - vertebrate animal models

In the last years host-microbe interactions and immune system responses in non-mammalian models like the fruit fly, Drosophila melanogaster were studied, directly related to gut colonization by biofilms. Non-mammalian models are suitable whenever quick, cheap and easily performable experiments are needed. The limitations of such models are revealed whenever more complex results are required e.g. immune reactions in response to biofilm-related infections. Also, the brief duration of these models, which in some cases is a strong advantage, may become a drawback which makes them not suitable for the research of chronic biofilm-related infections (39).

\section{Vertebrate animal models}

Experiments in quantification of microbial biofilm formation on CVC can lead to morbidity and mortality (40). In order to study biofilm formation on CVC in vivo, several animal models have been developed. These models allow researchers to study the efficacy of numerous antimicrobial agents, the stages of biofilm formation and the microbial dissemination to other organs and tissues. Among the initial experiments to be designed, a rat model was developed to study the biofilm generating capacity of $S$. aureus and S. epidermidis $(41,42)$.

Nowadays, various substrates are being tested for their effects on growth and development of biofilms using models which involve the subcutaneous implantation of foreign bodies $(43,44)$.

In vivo tissue - biofilm models

Infections related to biofilm growth and development have been simulated in living tissues, resulting in the design of biofilm models, with the purpose of overcoming the multiple diagnostic and treatment challenges.

In vivo models of tissue induced infections for biofilm study are numerous today such as: oral cavity infections (dental caries, periodontitis), ear, nose and throat infections (otitis media, rhino sinusitis), lung infections (cystic fibrosis, chronic obstructive pulmonary disease) UTI (cystitis, pyelonephritis), gastro-intestinal infections, wound infections, cardiac infections (endocarditis), osteomyelitis (40).

In vivo device related infections - biofilm models

Researchers have classified the in vivo models of infections originating from implanted medical devices into two groups. The first group of the biofilm models inserts the device (foreign-body) in the same organ / position as done in clinical settings e.g. intravascular catheter models or intrafemoral pins or wires. In the second group of biofilm models the foreign body is inserted in a subcutaneous pocket avoiding contact with any specific organ; these so-called "subcutaneous models" may be defined as tissue cage model, e.g. portions of catheters introduced subcutaneously. 
Frequently used in vivo devices for biofilm detection are: vascular catheters, endotracheal tubes, urinary catheters, orthopedic infections, prosthetic joints, vascular grafts, contact lenses, dental implants (45).

\section{Quantification and visualization of micro- bial biofilm}

As an alternative to techniques involving microtiter plates as growth support, researchers developed additional methods for quantitative biofilm analysis such as those determining the total biomass (i.e. matrix plus living and dead cells, e.g. crystal violet staining, Syto9 staining), those detecting and enumerating only viable sessile cells (e.g. resazurin staining) or the techniques which measure the amount of extracellular polymers in the biofilm matrix (e.g. dimethyl methylene blue staining) (28).

Scanning electron microscopy (SEM) is cited among the techniques allowing optimal visualization of the biofilm bacteria within the EPS, as well as of their direct attachment to the respective surface $(16,20,27,31)$.

For example, for the identification of biofilms in wounds, direct visualization by microscopy has been proposed, using a modified Congo Red solution, 57 SEM, epifluorescencemicroscopy, and confocal laser scanning microscopy (CLSM) (11).

The sampling error might though influence the accuracy of results. Preliminary sample processing by sonication improves bacterial recovery because, following this procedure, the EPS is fractured and bacteria are released into the sample. The next steps follow the classical bacteriological diagnosis with cultivation on enrichment media and identification by traditional techniques. While the bacteriological diagnosis remains the golden standard, improvements have been recently been proposed including the use of Polymerase Chain Reaction (PCR) for the detection of bacterial nucleic acids. Such techniques have advantages related to their increased sen- sitivity, specificity, and lower duration, but still, cannot discriminate between living and killed microorganisms. As a consequence, the risk of false positive results comes as a disadvantage. In order to support a more rapid diagnosis of biofilm-related infectious complications by PCRbased methods, Ryan S. et al. proposed a revised algorithm, to guide the plastic surgeon when facing complications that involve biofilms. They have highlighted that the management of recurrent capsular contracture in breast augmentation and biofilm reaction to soft-tissue fillers are important examples of how rapid polymerase chain reaction technology can contribute to build up a clinical algorithm for care that will help to choose a specific targeted antibiotic treatment (8).

More recently, fluorescent in situ hybridization, using a fluorescein labeled probe, specific for the $16 \mathrm{~S}$ ribosomal RNA of prokaryotic cells, was reported to bind and detect biofilm on surface samples. Once bound, the biofilm can be detected with CLSM or fluorescent microscopy $(17,31,46)$.

The structure analysis of the biofilm and extracellular matrix exopolysaccharide was done by CLSM in the tissue of the upper airway and oral cavity $(47,48)$. CLSM is superior to SEM because it does not require dehydration of the sample and consequently, the structure of a biofilm is better preserved. In a study on tonsillitis patients, Kania et al. (49) proved CLSM with double staining to be better than SEM in identifying mucosal biofilms.

CLSM software (e.g. COMSTAT), developed by (50) and (51) is used to quantify three-dimensional biofilm images of tremendous value in quantitative biofilm research. With this COMSTAT software, researchers can determine the mean thickness, roughness, substratum coverage and surface to volume ratio of biofilms (51).

Tomás I. et al. have analyzed in vivo human models of undisturbed oral biofilm by CLSM. They have used different types of oral appli- 
ances and substrates which were analyzed by several microbiological and microscopic methods in combination with CLSM. They have also discussed about a new microscopic technique called confocal endomicroscopy, which can be used for the in vivo microscopic investigation in the field of dentistry (52).

Chronic wounds represent a challenge because reliable markers are still needed for more accurate tests. At present, some promising methods are being tested such as metabolomic profiling (the study of small molecular metabolites), and genomic analysis (Quantitative or multiplex PCR) (41).

According to Deva et al., multiple diagnostic techniques must be combined in order to improve the diagnosis of biofilm contaminated medical devices with consecutive biofilm-related infections (31).

For example for analyzing biofilms by CLSM, researchers have used ultrasonic units for a gentle removal of biofilms from joint prostheses, internal fixation devices, vascular prostheses, cardiac pacemakers and defibrillators, dental implants, neurosurgical shunts or breast implants (27).

Sampedro et al. conducted a comparative study on spinal implant infection detected by conventional tissue culture and by a combined technique using preliminary sample preparation by vortexing and bath sonication in order to disrupt biofilms and release in-growing bacteria. The conclusions showed that the preliminary implant preparation by sonication followed by culture improved the sensitivity of biofilm bacterial detection and identification (53).

\section{Emerging methods for the treatment of biofilms}

The treatment of biofilm-related infections remains on the agenda of researchers worldwide, with certain experimental model treatments linked to molecular biology state-of-the-art techniques $(54,55)$. The major challenge is represented by the antibiotic resistance of bacteria growing in biofilms (56). There are promising results of vegetal extracts and essential oils which apparently could be involved in inhibiting the synthesis of the peptidoglycan component of the bacterial wall $(24,57)$.

For example Dorman and Deans (58) reported that phenolic structures of individual oil components presented wide spectrum antibacterial effects greatly dependent on their chemical structures. Encouraging results might be expected from strategies combining antibiotic therapies and essential oils. In a research conducted by Rodrigues et al. (59), the oil extracted from Croton zehntneri leaves was reported to enhance the effect of gentamicin against P.aeruginosa by $42.8 \%$ through gaseous contact supporting the use of essential oils as adjuvants of antibiotic therapies (59).

Regarding the prevention of biofilm formation, probiotic substances apparently offer further opportunities (60). Encouraging data regarding probiotics and their antimicrobial effects have been obtained by various research laboratories. Probiotics have proved to be effective in curing diseases such as dental caries, periodontal diseases, halitosis and candidiasis $(61,62,63)$.

Zambori et al. (64) have highlighted the antimicrobial potential of probiotics in vitro. More specifically, it was demonstrated that Lactobacillus casei, subsp. casei DG was effective in killing all dental plaque multidrug-resistant microbial species, while a mixed Lactobacillus acidophilus LA-5® and Bifidobacterium BB $-12 \circledR$ culture had a bacteriostatic effect. It has also been hypothesized that probiotics and prebiotics combined could act synergistically in supporting oral health (61).

Cotar et al. demonstrated by real time RTqPCR that in all P.aeruginosa strains grown in the presence of probiotic culture sterile filtrates, 
the level of QS genes expression was reduced comparatively with those from control cultures. Thereby the soluble molecules secreted by probiotics can inhibit the virulence factors regulation mechanisms and could represent a new pathway for pathogenicity and virulence attenuation in P.aeruginosa nosocomial strains (65).

According to Krespi et al., pulsed laser technology has the ability to generate a powerful pressure wave sufficient to effectively disrupt Pseudomonas biofilms in vitro, without visible damage to the underlying host structure. It also eliminates the ability of the remaining biofilm to receive nutrients from the external environment through its pores and web-like channels (66).

Mohammad Asnaasharia et al. (67) proposed photodynamic therapy (PDT) as an effective supplement in root canal disinfection. For this, the authors involved two PDT-based methods which were checked for their antibacterial effects. One of the methods used a light emitting diode lamp (LED lamp, $630 \mathrm{~nm}$ ) and the other involved the use of a diode laser (810 $\mathrm{nm})$. Both were tested on E. faecalis biofilms detected on extracted anterior human teeth. The PDT using the LED lamp was more effective in reducing the number of CFUs of E. faecalis in human teeth.

The attachment and growth of human microbial flora biofilm proved to be inhibited by a so-called photo functionalization therapy resulting in changed surface properties of titanium implants, as demonstrated by Dorigatti de Avila et al. (68).

Systemic treatment with linezolid was proposed by Fernández-Barat et al. to limit biofilm development and MRSA burden within ETT, in ventilated pigs with MRSA pneumonia (24).

Wolcott et al. proposed interventions combining debridement with specific anti-biofilm agents against bacterial phenotypes developing within biofilms. This novel approach of wound management which includes specially designed anti-biofilm measures had beneficial effects on wound healing demonstrating the utility of such interventions (69).

Hazer et al. designed an innovative spine implant model using modified pedicle Titanium (Ti) screws with the aim to check for anti-MRSA effects, if any. Implants were inserted in the lumbar spine of a rabbit, at multiple sites. The antimicrobial effect was illustrated by the inhibition of biofilm formation following the insertion of these modified Ti screws (70). Mechanical removal of the infected area or body part, e.g., dental infections is also indicated (12).

\section{Conclusions}

The cooperation between specialists in studies focusing on early detection of biofilm-associated infections and for the implementation of novel therapies and prevention methods seem attractive perspectives for the management of microbial biofilms.

Resolving pathologies caused by biofilms, require additional and/or alternative strategies like: the use of probiotics, prebiotics, essential oils; developing new methods in order to control pathogenic bacteria and favour the growth of non-pathogenic ones in biofilm communities; discovering new animal model systems in order to study in vivo polymicrobial biofilms; characterization of gene expression products of biofilm microorganisms, as well as clarifying the intimate mechanisms of inter-bacterial genetic material exchange within biofilms; mathematical modeling and computer simulation development which might contribute to important breakthrough results where biofilm-related infections are concerned. 


\section{Conflicts of interest}

The authors declare that they have no conflict of interest.
Abbreviations
EPS $=$ Extracellular polymeric substance
$\mathrm{CDC}=$ Centers for Disease Control and Prevention
ESGB = European Society of Clinical Microbiology and Infectious Dis- eases Biofilms study group
UTI = Urinary tract infections
GPB = Gram- positive bacteria
GNB = Gram-negative bacteria
$\mathrm{CVC}=$ Central venous catheters
$\mathrm{CFU}=$ Colony forming unit
ETT $=$ Endotracheal tubes
MRSA = Methicillin resistant Staphylococcus aureus
MTP = Microtitre plate assays
CFSTR $=$ Continuous flow stirred tank reactor
PFR = Plug flow reactor
$\mathrm{CDFF}=$ Constant depth film fermenter
TCP = Tissue culture plate
$\mathrm{TM}=$ Tube method
CRA = Congo Red Agar method
SEM = Scanning electron microscopy
CLSM = Confocal laser scanning microscopy
PCR = Polymerase chain reaction
PDT = Photodynamic therapy
Ti $=$ Titanium

\section{References}

1. Rao TV. Biofilms in infection. Available from http:// www.slideshare.net/doctorrao/biofilms-2172226.

2. Shunmgugaperumal T. Biofilm eradication and prevention, a pharmaceutical approach to medical device infections. Edited by John Wiley \& Sons, New Jersey. 2010;3-36;116-151. Available from:www.formatex. info/microbiology3/book/896-905.pdf.
3. Rabin N, Zheng Y, Opoku-Temeng C, Du Y, Bonsu E, Sintim HO. Biofilm formation mechanisms and targets for developing antibiofilm agents. Future Med Chem. 2015;7(4):493-512. DOI: 10.4155/fmc.15.6.

4. Donlan RM. Biofilms and device-associated infections. Available from: http://wwwnc.cdc.gov/eid/article/7/2/70-0277_article.

5. http://www.escmid.org/research_projects/study_ groups/biofilms/presentations_publications/.

6. Hoiby N, Bjarnsholt T, Moser C, Bassi GL, Coenye T, Donelli G, et al. ESCMID guideline for the diagnosis and treatment of biofilm infections 2014. Clin Microbiol Infect. 2015 May;21 Suppl 1:S1-25. DOI: 10.1016/j.cmi.2014.10.024.

7. Hope CK, Wilson M. Biofilm structure and cell vitality in a laboratory model of subgingival plaque. J Microbiol Methods. 2006 Sep;66(3):390-8. DOI: 10.1016/j.mimet.2006.01.003.

8. Constantine RS, Constantine FC, Rohrich RJ. The ever-changing role of biofilms in plastic surgery. Plast Reconstr Surg. 2014 Jun;133(6):865e-872e. DOI: 10.1097/PRS.0000000000000213.

9. Castrillón Rivera LE, Palma RA. Biofilms:A survival and resistance mechanism of microorganisms. Available from:www.intechopen.com.

10. Pace JL, Rupp ME, Finch RG. Biofilms, infection and antimicrobial therapy. Edited by Press Taylor \& Francis Group. 2006;39-51.

11. Vyas KS, Wong LK. Detection of biofilm in wounds as an early indicator for risk for tissue infection and wound chronicity. Ann Plast Surg. 2016 Jan;76(1):12731. DOI: $10.1097 /$ SAP.0000000000000440.

12. Bjarnsholt $\mathrm{T}$. The role of bacterial biofilms in chronic infections. APMIS Suppl. 2013 May;(136):1-51.

13. Dower R, Turner ML. Pilot study of timing of biofilm formation on closed suction wound drains. Plast Reconstr Surg. 2012;130(5):1141-6. DOI: 10.1097/ PRS.0b013e318267d54e.

14. Rouabhia M, Chmielewski W. Diseases associated with oral polymicrobial biofilms. Open Mycol J. 2012;6:2732. DOI: $10.2174 / 1874437001206010027$.

15. Augustin M, Chifiriuc CB, Lazăr V, Stănescu R, Burlibaşa M, Ispas DC. Microbial biofilms in dental medicine in reference to implanto-prostethic rehabilitation. Rev. chir. oro-maxilo-fac. implantol., 2010; 1(1) 9-13. 
16. Jacombs A, Tahir S, Honghua $\mathrm{H}$, et al. In vitro and in vivo investigation of the influence of implant surface on the formation of bacterial biofilm in mammary implants. Plast Reconstr Surg. 2014 Apr;133(4):471e-80e. DOI: 10.1097/PRS.0000000000000020.

17. Hu H, Johani K, Almatroudi A, Vickery K, Van Natta $\mathrm{B}, \mathrm{Kadin} \mathrm{ME}$, et al. Bacterial biofilm infection detected in breast implant-associated anaplastic large-cell lymphoma. Plast Reconstr Surg. 2016 Jun;137(6):1659-69. DOI: $10.1097 /$ PRS.0000000000002010.

18. Szczotka-Flynn LB, Imamura Y, Chandra J, Yu C, Mukherjee PK, Pearlman E, et al. Increased resistance of contact lens-related bacterial biofilms to antimicrobial activity of soft contact lens care solutions. Cornea. 2009 Sep;28(8):918-26. DOI: 10.1097/ ICO.0b013e3181a81835.

19. Brothers KM, Nau AC, Romanowski EG, Shanks RM. Dexamethasone diffusion across contact lenses is inhibited by Staphylococcus epidermidis biofilms in vitro. Cornea. 2014 Oct; 33(10):1083-7. DOI: 10.1097/ ICO.0000000000000196.

20. Sivaraman KR, Hou JH, Chang JH, Behlau I, Cortina MS, Cruz J de L. Scanning electron microscopic analysis of biofilm formation in explanted human Boston type I keratoprostheses. Cornea. 2016 Jan;35(1):25-9. DOI: 10.1097/ICO.0000000000000674.

21. Bannister B, Gillespie S, Jones J. Infection:Microbiology and Management. Third Edition. Edited by Blackwell Publishing Ltd, 2006;226-238.

22. Miquel S, Lagrafeuille R, Souweine B, Forestier C. Anti-biofilm Activity as a Health Issue. Front Microbiol. 2016; 7:592. DOI: 10.3389/fmicb.2016.00592.

23. Wilson A, Gray D, Karakiozis J, Thomas J. Advanced endotracheal tube biofilm stage, not duration of intubation, is related to pneumonia. J Trauma Acute Care Surg. 2012 Apr;72(4):916-23. DOI: 10.1097/ TA.0b013e3182493a10.

24. Fernández-Barat L, Ferrer M, Sierra JM, Soy D, Guerrero L, Vila J, et al. Linezolid limits burden of methicillin-resistant Staphylococcus aureus in biofilm of tracheal tubes. Crit Care Med. 2012 Aug;40(8):2385-9. DOI: 10.1097/ CCM.0b013e31825332fc.

25. Hell M. Prevention of waterborne infections - what can be done?. Int J Infect Control. 2016;2(Suppl.1):25-26.
26. Kouidhi B, Al Qurashi YMA, Chaieb K. Review drug resistance of bacterial dental biofilm and the potential use of natural compounds as alternative for prevention and treatment. Microb Pathog. 2015 Mar;80:39-49. DOI: 10.1016/j.micpath.2015.02.007.

27. Arad E, Navon-Venezia S, Gur E, Kuzmenko B, Glick R, Frenkiel-Krispin D, et al. Novel rat model of methicillin-resistant Staphylococcus aureus-infected silicone breast implants:A study of biofilm pathogenesis. Plast Reconstr Surg. 2013 Feb;131(2):205-14. DOI: 10.1097/PRS.0b013e3182778590.

28. Lazar V, Chifiriuc MC. Mechanisms and experimental models for the assessment of microbial biofilms' phenotypical resistance / tolerance. Science against microbial pathogens:communicating current research and technological advances. A. Méndez-Vilas (Ed.), 2011, 906 -911.

29. Brackman G., Coenye T. Quorum Sensing Inhibitors as Anti-Biofilm Agents. Current Pharmaceutical Design, 2015;21(1):5-11. DOI: 10.2174/138161282066614090 5114627.

30. Lazar V. Quorum sensing in biofilms--how to destroy the bacterial citadels or their cohesion/power? Anaerobe. 2011;17(6):280-5. DOI: 10.1016/j.anaerobe.2011.03.023.

31. Deva AK, Adams WP, Vickery K. The role of bacterial biofilms in device-associated infection. Plast Reconstr Surg. 2013 Nov;132(5):1319-28. DOI: 10.1097/ PRS.0b013e3182a3c105.

32. Niu C, Gilbert ES. Colorimetric method for identifying plant essential oil components that affect biofilm formation and structure. Appl Environ Microbiol. 2004;70:6951-6. DOI: 10.1128/AEM.70.12.6951-6956.2004.

33. Coenye T, Nelisa HJ. In vitro and in vivo model systems to study microbial biofilm formation. J Microbiol Methods. 2010;83(2):89-105. DOI: 10.1016/j.mimet.2010.08.018.

34. Zambori C, Morvay AA, Gurban C, Licker M, Tănăsie G, Colibar O, et al. Biofilm formation of Staphylococcus, Streptococcus, Pasteurella and Neisseria strains. Romanian Biotechnological Letters. 2015;20(4):10718-26.

35. Kosikowska U, Głowniak IK, Niedzielski A, Malm A. Nasopharyngeal and adenoid colonization by Haemophilus influenzae and Haemophilus parainfluenzae in children undergoing adenoidectomy and the ability of bacterial isolates to biofilm production. Medicine. 2015 May;94(18):e799. DOI: 10.1097/MD.0000000000000799. 
36. Heersink J, Goeres D. Reactor design considerations. In:Hamilton M, Heersink J, Buckingham-Meyer K, Goeres D. The biofilm laboratory:Step-by-step protocols for experimental design, analysis, and data interpretation. Edited by Cytergy Publishing. 2003;13-15.

37. Busscher HJ, Van der Mei HC. Microbial adhesion in flow displacement systems. Clin Microbiol Rev. 2006;19:127-41. DOI: 10.1128/CMR.19.1.127141.2006 .

38. Hassan A, Usman J, Kaleem F, Omair M, Khalid A, Iqbal M. Evaluation of different detection methods of biofilm formation in the clinical isolates. Braz $\mathrm{J}$ Infect Dis. 2011;15(4):305-11. DOI: $10.1590 / \mathrm{S} 1413-$ 86702011000400002 .

39. Lemaitre B, Ausubel F. Animal models for host-pathogen interactions. Curr Opin Microbiol. 2008;11:24950. DOI: 10.1016/j.mib.2008.05.002.

40. Donlan RM. Biofilms on central venous catheters:is eradication possible?, Curr Top Microbiol Immunol. 2008;322:133-61. DOI: 10.1007/978-3-540-75418-3_7.

41. Ulphani JS, Rupp ME. Model of Staphylococcus aureus central venous catheter-associated infection in rats. Lab Anim Sci. 1999;49:283-7.

42. Rupp ME, Ulphani JS, Fey PD Mack D. Characterization of Staphylococcus epidermidis polysaccharide intercellular adhesin/hemagglutinin in the pathogenesis of intravascular catheter-associated infection in a rat model. Infect Immun. 1999;67:2656-9.

43. Nakamoto DA, Haaga JR, Bove P, Merritt K, Rowland DY. Use of fibrinolytic agents to coat wire implants to decrease infection. An animal model. Invest Radiol. 1995;30:341-4. DOI: 10.1097/00004424-19950600000003.

44. Engelsman AF, Van der Mei HC, Francis KP, Busscher HJ, Ploeg RJ, van Dam GM. Real time noninvasive monitoring of contaminating bacteria in a soft tissue implant infection model. J Biomed Mater Res B Appl Biomater. 2009 Jan;88(1):123-9. DOI: 10.1002/ jbm.b.31158.

45. Lebeaux D, Ashwini C, Rendueles O, Beloin C. From in vitro to in vivo models of bacterial biofilm-related infections. Pathogens. 2013 Jun;2(2):288-356. DOI: 10.3390/pathogens2020288.

46. Motta JP, Flannigan KL, Agbor TA, Beatty JK, Blackler RW, Workentine ML, et al. Hydrogen sulfide protects from colitis and restores intestinal microbiota biofilm and mucus production. Inflamm Bowel Dis. 2015 May;21(5):1006-17. DOI: 10.1097/ MIB.0000000000000345.

47. Paraje MG. Confocal scanning laser microscopy in the study of biofilm formation in tissues of the upper airway in otolaryngologic diseases. In:Méndez-Vilas A, Diaz J. Microscopy:Science, Technology, Applications and Education. Edited by FORMATEX. 2010;590-6.

48. Burmeister M, Von Schwanewede H, Stave J, Guthoff RF. Intraoral diagnostics using confocal laser scanning microscopy. Biomed Tech. 2009;54:23-28. DOI: 10.1515/BMT.2009.004.

49. Kania RE, Lamers GE, Vonk MJ, Huy PT, Hiemstra PS, Bloemberg GV, Grote JJ. Demonstration of bacterial cells and glycocalyx in biofilms on human tonsils. Arch Otolaryngol Head Neck Surg. 2007;133(2):115-121. DOI: 10.1001/archotol.133.2.115.

50. Heydorn A, Ersbøll BK, Hentzer M, Parsek MR, Givskov M, Molin S. Experimental reproducibility in flow-chamber biofilms. Microbiology. 2000 Oct;146 (Pt10) :2409-15. DOI: 10.1099/00221287-146-102409.

51. Heydorn A, Nielsen AT, Hentzer M, Sternberg C, Givskov M, Ersbøll BK, et al. Quantification of biofilm structures by the novel computer program COMSTAT. Microbiology. 2000 Oct;146 (Pt10) :2395-407. DOI: 10.1099/00221287-146-10-2395.

52. Tomás I, Henderson B, Diz P, Donos N. In vivo oral biofilm analysis by confocal laser scanning microscopy:methodological approaches. In:Méndez-Vilas A, Diaz J. Microscopy:Science, Technology, Applications and Education. Edited by FORMATEX. 2010;597-606.

53. Sampedro MF, Huddleston PM, Piper KE, Karau $\mathrm{MJ}$, et al. A biofilm approach to detect bacteria on removed spinal implants. Spine (Phila $\mathrm{Pa}$ 1976). 2010 May;35(12):1218-24. DOI: 10.1097/ BRS.0b013e3181c3b2f3.

54. Lazăr V, Chifiriuc MC. Medical significance and new therapeutical strategies for biofilm associated infections. Roum Arch Microbiol Immunol. 2010;69(3):12538.

55. Chifiriuc MC, Ficai A, Lazar, V AM, Ditu LM, Popa M, Iordache C, Holban AM, Şerban Beresteanu SVG, Grigore R, Lazar V. Soft tissue engineering and microbial infections:Challenges and perspectives, 2016, vol 5, 1-29. 
56. Lazar V, Bezirtzouglou E. Microbial biofilms IN Medical sciences. http://www.eolss.net/EolsssampleAllChapter.aspx.

57. György É. Study of the antimicrobial activity and synergistic effect of some plant extracts and essential oils. Rev Romana Med Lab. 2010;18(1):49-56.

58. Dorman HJ, Deans SG. Antimicrobial agents from plants:antibacterial activity of plant volatile oils. J Appl Microbiol. 2000;88(2):308-16. DOI: 10.1046/j.13652672.2000.00969.x.

59. Rodrigues FF, Costa JG, Coutinho HD. Synergy effects of the antibiotics gentamicin and the essential oil of Croton zehntneri. Phytomedicine. 2009Nov;16(11):1052-5. DOI: 10.1016/j.phymed.2009.04.004.

60. Zambori C, Cumpănăşoiu C, Moţ D, Huţu I, Gurban C, Tîrziu E. The antimicrobial role of probiotics in the oral cavity in humans and dogs. Animal Science and Biotechnologies. 2014;47(1):126-30.

61. Sudhakar RR, Swapna LA, Ramesh T, Rajesh TS, Vijayalaxmi N, Lavanya R. Bacteria in oral health - probiotics and prebiotics. Int $\mathrm{J}$ Biol Med Res. 2011;2(4):1226 -33.

62. Pradeep K, Kuttapa MA, Prassana KR. Probiotics and oral health:an update. SADJ. 2014 Feb;69(1):20-4.

63. Agarwal E, Bajaj P, Guruprasad CN, Naik S, Pradeep AR. Probiotics:a novel step towards oral health. AOSR. 2011;1(2):108-15.

64. Zambori C, Morvay AA, Sala C, Licker M, Gurban C, Tanasie G, et al. Antimicrobial effect of probiotics on bacterial species from dental plaque. J Infect Dev Ctries. 2016 Mar;10(3):214-21. DOI: 10.3855/ jidc. 6800 .
65. Cotar AI, Chifiriuc MC, Dinu S, Pelinescu D, Banu O, Lazãr V. Quantitative real-time pcr study of the influence of probiotic culture soluble fraction on the expression of pseudomonas aeruginosa quorum sensing genes. Romanian archives of Microbiology and Immunology, 2010; 69(4):213-223.

66. Krespi YP, Stoodley P, Hall-Stoodley L. Laser disruption of biofilm. Laryngoscope. 2008 Jul;118(7):116873. DOI: 10.1097/MLG.0b013e31816ed59d.

67. Mohammad A, Seyed MM, Zahra A, Saranaz AM, Alireza M. A comparison of the antibacterial activity of the two methods of photodynamic therapy (using diode laser $810 \mathrm{~nm}$ and LED lamp $630 \mathrm{~nm}$ ) against Enterococcus faecalis in extracted human anterior teeth. Photodiagnosis Photodyn Ther. 2016;13:233-37. DOI: 10.1016/j.pdpdt.2015.07.171.

68. de Avila ED, Lima BP, Sekiya T, Torii Y, Ogawa T, Shi $\mathrm{W}$, et al. Effect of UV-photofunctionalization on oral bacterial attachment and biofilm formation to titanium implant material. Biomaterials. 2015 Oct;67:84-92. DOI: $10.1016 /$ j.biomaterials.2015.07.030.

69. WolcottR, Dowd CWS. The Role of biofilms:are we hitting the right target? Plast Reconstr Surg. 2011 Jan;127(1):28S35S. DOI: 10.1097/PRS.0b013e3181fca244.

70. Hazer DB, Sakar M, Dere Y, Altinkanat G, Ziyal MI, Hazer B. Antimicrobial effect of polymer-based silver nanoparticle coated pedicle screws:experimental research on biofilm inhibition in rabbits. Spine (Phila $\mathrm{Pa}$ 1976). 2016 Mar;41(6):E323-9. DOI: 10.1097/ BRS.0000000000001223. 